\title{
An Inducible Xylanase of the Mushroom Termitomyces clypeatus Differing from the Xylanase/Amylase Produced in Dextrin Medium
}

\author{
By M. MUKHERJEE AND S. SENGUPTA* \\ Indian Institute of Chemical Biology, 4 Raja S. C. Mullick Road, Jadavpur, Calcutta 700032, \\ India
}

(Received 1 October 1984; revised 10 January 1985)

The mushroom Termitomyces clypeatus produces a single endoxylanase (1,4- $\beta$-D-xylan xylanohydrolase, EC 3.2.1.8) in the presence of either dextrin or xylan as sole source of carbon. The enzymes produced in the two conditions are different. The enzyme induced by xylan has been purified 67-fold from the culture filtrate of $T$. clypeatus. The enzyme preparation gave a single protein band on SDS-PAGE, corresponding to a molecular weight of about 24000 . The enzyme has an isoelectric point at $\mathrm{pH} 4.0$ and acts on arabinoxylan and arabinogalactan, but not amylopectin or galactomannan. It shows maximum activity on xylan $(1,4-\beta$-linked $D$ xylopyranose units) at $\mathrm{pH} 3.5$ and $55^{\circ} \mathrm{C}$ and is fairly stable up to $60^{\circ} \mathrm{C}$. The $K_{\mathrm{m}}$ for xylan is $4 \mathrm{mg}$ $\mathrm{ml}^{-1} . \mathrm{Hg}^{2+}, \mathrm{Fe}^{2+}$ and $\mathrm{Ag}^{+}$are the most potent inhibitors of the enzyme. The $\mathrm{pH}$ optimum and molecular weight of this inducible xylanase differ from those of the enzyme produced by the same organism grown in dextrin medium.

\section{INTRODUCTION}

Xylanase is a hydrolytic enzyme that splits $1,4-\beta$-linked glycosidic bonds of $\mathbf{D}$-xylopyranoside units of the hemicellulose xylan. This enzyme has been purified from various fungal and bacterial sources (Dekker \& Richards, 1976), including the mushroom Termitomyces clypeatus grown submerged in dextrin/salt medium (Ghosh et al., 1980). In the latter case, the electrophoretically homogeneous enzyme, of molecular weight 90000 , had amylolytic as well as xylanolytic activity.

In the present study it is shown that the same strain of $T$. clypeatus also liberates xylanase when grown with xylan as sole source of carbon; under these conditions no amylase activity is detectable. The xylanase induced by xylan has been compared with the xylanase/amylase activities purified earlier from same source, and is shown to be a different enzyme.

\section{METHODS}

Growth medium and conditions. The synthetic medium used for the growth of $T$. clypeatus was described by Ghosh \& Sengupta (1978). For production of the xylan-induced enzyme, the fungus was grown submerged at $30^{\circ} \mathrm{C}$ for $5 \mathrm{~d}$ in the same medium, but containing $1 \%(\mathrm{w} / \mathrm{v})$ xylan as carbon source in place of dextrin.

Chemicals. Xylan (1,4- $\beta$-linked), DEAE-Sephadex (A-50), methyl $\alpha$-D-xylopyranoside, methyl $\beta$-D-xylopyranoside, amylopectin azure, 1-O-methyl $\alpha$-D-galactopyranoside, $1-O$-methyl $\beta$-D-galactopyranoside, arabinogalactan, carboxymethylcellulose (low viscosity), albumin, $\beta$-lactoglobulin, lysozyme, ovalbumin, pepsin, trypsin and trypsinogen were purchased from Sigma. Arabinoxylan (arabinose 34.1\% and xylan 65.9\%) was a gift from Dr G. B. Fincher, La Trobe University, Bundoora, Australia. Bio-Gel P-200 and Bio-Gel P-60 were from Bio-Rad, iodoacetic acid and EDTA from Merck, and Pharmalyte ( $\mathrm{pH}$ 3-10) from Pharmacia. Other chemicals used were of chemically pure quality.

Assay of xylanase activity. This was done by measuring the amount of reducing sugar liberated, according to the method of Nelson (1944) as modified by Somogyi (1952). The assay mixture contained $0.1 \mathrm{ml}$ culture filtrate or enzyme solution, $0.1 \mathrm{ml}$ xylan $\left(10 \mathrm{mg} \mathrm{ml}^{-1}\right.$ in $0.1 \mathrm{M}$-acetate buffer, $\left.\mathrm{pH} 5.0\right)$ and $0.2 \mathrm{ml}$ of the same buffer. The mixture was incubated for $30 \mathrm{~min}$ at $40^{\circ} \mathrm{C}$ and the reaction was stopped by adding $0.4 \mathrm{ml}$ alkaline copper reagent. 
The mixture was kept for $10 \mathrm{~min}$ in a boiling water bath and cooled, then $0.2 \mathrm{ml}$ arsenomolybdate reagent was added. After $15 \mathrm{~min}$ the mixture was centrifuged. The supernatant was diluted fivefold with water and the $A_{500}$ was measured. (Amylase activity was assayed similarly, but using starch instead of xylan.) Readings were expressed in terms of xylose equivalents. One unit of enzyme activity (U) is the amount of enzyme which produces $1 \mu \mathrm{mol} \mathrm{D}$-xylose $\mathrm{min}^{-1}$ under the assay conditions.

Protein determination. Protein was determined by the Lowry method with bovine serum albumin as the standard.

$P A G E$. For activity staining of concentrated culture supernatant, electrophoresis was done in glycine/Tris buffer, pH 8.3, using 7.5\% (w/v) acrylamide (Davis, 1964). A constant current of $2.5 \mathrm{~mA}$ per gel $(7.0 \mathrm{~cm}) \cdot \mathrm{was}$ applied for $2 \mathrm{~h}$ at $25^{\circ} \mathrm{C}$. Gels were stained with Coomassie brilliant blue for $2 \mathrm{~h}$ and destained with methanol/acetic acid/water.

For molecular weight determination, the $\beta$-mercaptoethanol treated enzyme was subjected to SDS-PAGE using $10 \%$ acrylamide according to Laemmli (1970). A constant current of $1.5 \mathrm{~mA}$ per gel $(11.5 \mathrm{~cm})$ was applied for $1 \mathrm{~h}$ at $25^{\circ} \mathrm{C}$.

Isoelectric focusing of xylanase. Analytical isoelectrophoresis was done with $5 \%$ acrylamide containing $2 \%(\mathrm{v} / \mathrm{v})$ carrier ampholyte (Pharmalytes, pH 3-10) according to Cisar et al. (1975). Gels were fixed overnight in 10\%(w/v) trichloroacetic acid containing $5 \%(\mathrm{w} / \mathrm{v})$ sulphosalicylic acid, and rinsed several times with the same solution to remove carrier ampholyte before staining. Finally the gel was stained with Coomassie brilliant blue for $18 \mathrm{~h}$ and destained with acetic acid/methanol/water.

The pI was determined by co-electrophoresis of the enzyme with standard proteins of known pI: myoglobin (pI 6.85 and 7.35), soybean trypsin inhibitor (4.5) and horse gram lectin (5.1). The pI was determined from a graph of the pI values of the standard proteins against distance migrated from the anode (Rufo et al., 1982).

$P A G E$ of culture filtrate and assay of gels for xylanase and amylase activity. Culture filtrates of the mushroom grown in the presence of either dextrin or xylan were freeze-dried, dissolved in $0 \cdot 1 \mathrm{M}$-acetate buffer, $\mathrm{pH} 5 \cdot 0$, and dialysed against the same buffer. Then $105 \mu \mathrm{g}$ and $90 \mu \mathrm{g}$ protein of culture filtrate from dextrin and xylan medium, respectively, were subjected to electrophoresis on $7 \cdot 5 \%$ polyacrylamide gels at $\mathrm{pH} 8 \cdot 3$. After electrophoresis one gel was stained as described above, while the second gel was disssected, macerated in $0 \cdot 1 \mathrm{M}$-acetate buffer, $\mathrm{pH} 5 \cdot 0$, centrifuged and assayed for xylanase and amylase activity in the supernatants.

Purification of xylanase. This was done at $4^{\circ} \mathrm{C}$ using the following steps.

(i) Ultrafiltration (PM-10). The broth (1 litre), filtered through Whatman no. 1 filter paper, was concentrated by ultrafiltration using a PM-10 membrane. The concentrated filtrate $(35 \mathrm{ml}$ ) was dialysed against $0.01 \mathrm{M}$-acetate buffer, pH $5 \cdot 0$.

(ii) Chromatography on DEAE-Sephadex (A-50). The enzyme solution was applied to a $3.8 \times 18.0 \mathrm{~cm}$ column of DEAE-Sephadex (A-50) which had been equilibrated with $0.01 \mathrm{M}$-acetate buffer, $\mathrm{pH} 5 \cdot 0$, and eluted with the same buffer at a flow rate of $12 \mathrm{ml} \mathrm{h}^{-1}$. After passing 4 bed volumes of the buffer, a $0-1 \mathrm{M}$ linear $\mathrm{NaCl}$ gradient was used. Fractions $(7 \mathrm{ml}$ ) eluted with $\mathrm{NaCl}$ and containing xylanase activity were reduced to $2 \mathrm{ml}$ by freeze-drying and dialysed against acetate buffer.

(iii) Chromatography on Bio-Gel P-200. Enzyme was applied to a $2 \times 51 \mathrm{~cm}$ column, equilibrated with $0 \cdot 1 \mathrm{M}-$ acetate buffer, pH 5.0, and eluted with the same buffer at a rate of $6 \mathrm{ml} \mathrm{h}^{-1}$. Fractions $(2.5 \mathrm{ml})$ showing activity (33-41) were concentrated and dialysed.

(iv) Chromatography on Bio-Gel P-60. Dialysed enzyme (1 ml) from step (iii) was applied to the column $(1.4 \times$ $26 \mathrm{~cm}$ ) and eluted with $0.1 \mathrm{M}$-acetate buffer, $\mathrm{pH} 5 \cdot 0$, at a rate of $8 \mathrm{ml} \mathrm{h}^{-1}$. Fractions $(1 \mathrm{ml})$ showing enzyme activity (18-26) were freeze-dried and used as enzyme source for further studies.

Studies on the properties of the purified enzyme.

(a) Optimum temperature. Xylanase activity in $0.1 \mathrm{M}$-acetate buffer, $\mathrm{pH} 5.0$, was measured at different temperatures in the range $10-80^{\circ} \mathrm{C}$.

(b) Thermal stability. Enzyme solution $\left(30 \mu \mathrm{g}\right.$ protein $\left.\mathrm{ml}^{-1}\right)$ was kept at $\mathrm{pH} 5.0$ in $0.1 \mathrm{M}$-acetate buffer for $1 \mathrm{~h}$ at different temperatures $\left(20-80^{\circ} \mathrm{C}\right)$ and residual enzyme activity was measured.

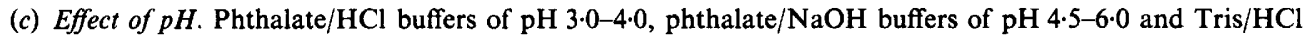
buffers of $\mathrm{pH} 7 \cdot 0-9 \cdot 0$ were used to determine the optimum $\mathrm{pH}$ for enzyme activity.

(d) Effect of metal ions and inhibitors. Enzyme activity was measured in presence of the compounds in $0 \cdot 1 \mathrm{M}-$ acetate buffer, pH 5.0.

(e) Effect of substrate concentration. Variable amounts $(0 \cdot 2-8 \mathrm{mg})$ of xylan in $0 \cdot 1 \mathrm{M}$-acetate buffer, $\mathrm{pH} 5 \cdot 0$, were incubated with the same amount of enzyme $\left(1.4 \times 10^{-2}\right.$ units).

(f) Activity towards different substrates. Different carbohydrates $\left(10 \mathrm{mg} \mathrm{m}^{-1}\right)$ including xylan were incubated for $30 \mathrm{~min}$ in $0.1 \mathrm{M}$-acetate buffer, $\mathrm{pH} 5.0$, with the same amount of enzyme $\left(1.4 \times 10^{-2}\right.$ units).

Chromatography of the products of hydrolysis. The reaction mixture contained $2 \mathrm{ml} 1 \%(\mathrm{w} / \mathrm{v})$ xylan in $0 \cdot 1 \mathrm{M}-$ acetate buffer, $\mathrm{pH} 5 \cdot 0$, and $0 \cdot 1 \mathrm{ml}$ enzyme $\left(30 \mu \mathrm{g}\right.$ protein $\left.\mathrm{ml}^{-1}\right)$. Samples taken at various times were assayed for 
liberated xylose and smaller oligosaccharides. Clear supernatants were chromatographed on Whatman no. 1 paper in butanol/pyridine/water $(60: 40: 30$, by vol.). Spots were detected on the chromatogram with aniline oxalate reagent. Xylose was chromatographed as reference sugar.

\section{RESULTS}

Concentrated culture filtrates of $T$. clypeatus grown with dextrin or xylan as sole source of carbon were subjected to PAGE and the gels were assayed for xylanase and amylase activities (Fig. 1). Single peaks of xylanase activity were obtained for both the culture filtrates but the electrophoretic mobilities of the proteins were different. There was no amylase activity in the preparation from the xylan-grown culture. The enzyme from the culture filtrate of the fungus grown in xylan medium was purified to homogeneity as judged by SDS-PAGE (Table 1).

Isoelectric focusing of the purified xylanase gave a single packed band with a pI of 4.0. The molecular weight of the xylanase was determined as 24000 by SDS-PAGE and as 22000 by chromatography on Bio-Gel P-200. The enzyme gave a single protein band on SDS-PAGE, suggesting that it is a single polypeptide.

\section{Properties of the purified enzyme}

The enzyme showed optimum activity at $55^{\circ} \mathrm{C}$ with xylan as the substrate. It was stable at $30{ }^{\circ} \mathrm{C}$ and below but lost activity at higher temperatures $(70 \%$ and $100 \%$ loss of activity on incubation for $1 \mathrm{~h}$ at $60^{\circ} \mathrm{C}$ and $70^{\circ} \mathrm{C}$, respectively). The optimum pH for xylanase activity was 3.5: activity was about $50 \%$ of the optimum at $\mathrm{pH} 5 \cdot 0$, and there was total loss of activity at $\mathrm{pH} 6 \cdot 0$.

The activity of the enzyme at $\mathrm{pH} 5.0$ was inhibited strongly by $\mathrm{Hg}^{2+}, \mathrm{Ag}^{+}$and $\mathrm{Fe}^{2+}$, moderately by $\mathrm{Cu}^{2+}$ and $\mathrm{Zn}^{2+}$ and insignificantly by $\mathrm{Mg}^{2+}$ and $\mathrm{Ca}^{2+}$ at $20 \mathrm{mM}$ concentration. EDTA was strongly inhibitory but iodoacetate and $\mathrm{NaN}_{3}$ did not inhibit the enzyme. The $K_{\mathrm{m}}$ and $V_{\max }$ values of the enzyme, calculated from a Lineweaver-Burk plot, were $4 \mathrm{mg} \mathrm{xylan} \mathrm{ml}^{-1}$ and $1.5 \times 10^{-3} \mu \mathrm{mol}$ xylose $\mathrm{min}^{-1} \mu \mathrm{g}^{-1}$ respectively.

The enzyme had no $\alpha$ - or $\beta$-xylopyranosidase or galactopyranosidase activity. Cellulose, carboxymethylcellulose, starch, amylopectin and galactomannan were not attacked by the enzyme but appreciable amounts of reducing sugar were liberated from arabinogalactan and arabinoxylan. The activity of the enzyme against arabinogalactan was rather more than half of its activity against xylan.

The mode of liberation of reducing sugar from xylan by the action of the enzyme was followed by paper chromatography of the reaction mixtures. Small oligosaccharides were present during the first $24 \mathrm{~h}$ of incubation. Xylose was only detected after $36 \mathrm{~h}$ of incubation, with the concomitant disappearance of all except one of the oligosaccharides. This oligosaccharide was present in comparable amounts to xylose, but was not identified.

\section{DISCUSSION}

An extracellular endoxylanase from the culture filtrate of $T$. clypeatus grown with dextrin as carbon source was purified by Ghosh et al. (1980) and found to be a single polypeptide of molecular weight 90000 , having both xylanase and amylase activities. In the present study we showed that $T$. clypeatus also liberates xylanase when grown with xylan as carbon source, and no amylase activity could be detected in the culture filtrate. Electrophoresis of culture filtrates showed that the xylanases produced in the presence of the two different carbon sources are different.

The molecular weight of the xylanase liberated in xylan medium (24000) is much smaller than that of the enzyme that Ghosh et al. (1980) purified (90000), but most of the other properties studied are very similar for the two enzymes, e.g. temperature optima, substrate specificity, $K_{\mathrm{m}}$ values, thermal stability. The enzyme liberated in xylan medium, like the other enzyme, is an endoxylanase. There are slight differences between the enzymes in susceptibility to chemical agents and in $V_{\max }$ values. However, the most remarkable difference identified is in the $\mathrm{pH}$ 

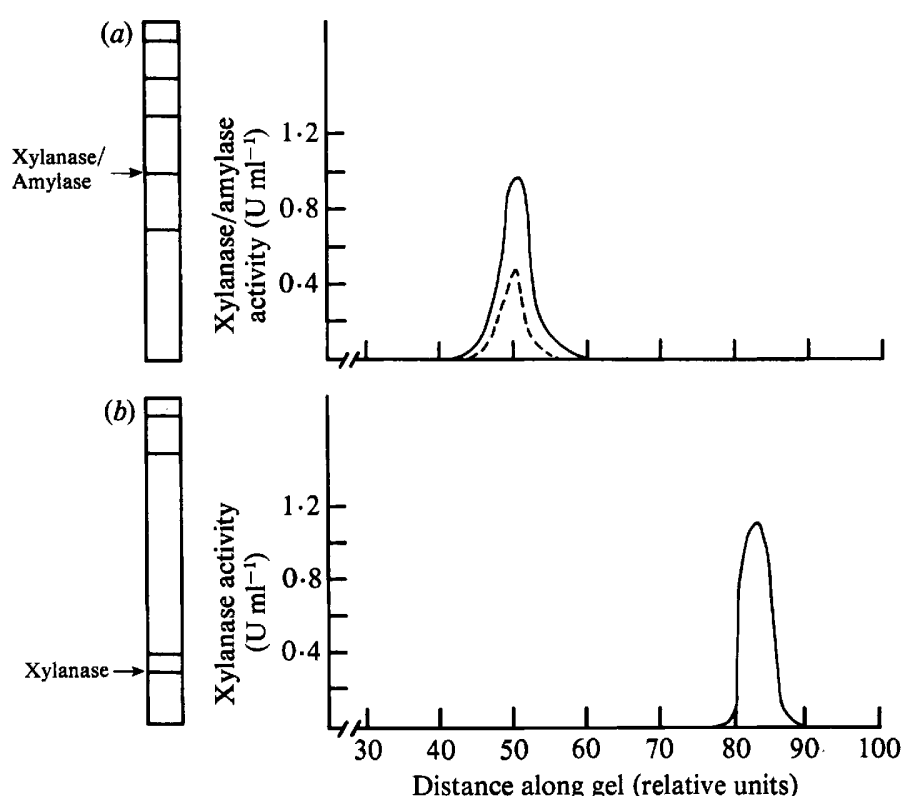

Fig. 1. PAGE of culture filtrates of $T$. clypeatus grown with $(a)$ dextrin or $(b)$ xylan as the sole carbon source, and assay of the gels for xylanase (-) and amylase (---) activities.

Table 1. Purification of xylanase from the culture filtrate of $T$. clypeatus

\begin{tabular}{|c|c|c|c|c|c|}
\hline Enzyme sample & $\begin{array}{l}\text { Protein } \\
\text { (mg) }\end{array}$ & $\begin{array}{l}\text { Total activity } \\
\text { (U) }\end{array}$ & $\begin{array}{l}\text { Specific activity } \\
{\left[\mathrm{U}(\mathrm{mg} \text { protein })^{-1}\right]}\end{array}$ & $\begin{array}{l}\text { Recovery } \\
\text { yield }(\%)\end{array}$ & $\begin{array}{l}\text { Purification } \\
\text { (fold) }\end{array}$ \\
\hline Culture filtrate & $40 \cdot 6$ & $\begin{array}{l}30.4 \\
28.5\end{array}$ & $\begin{array}{l}0.75 \\
0.81\end{array}$ & $\begin{array}{r}100 \\
94\end{array}$ & 1 \\
\hline $\begin{array}{l}\text { Ultrafiltrate (PM-10) } \\
(35 \mathrm{ml})\end{array}$ & & & & & \\
\hline $\begin{array}{l}\text { DEAE-Sephadex (A-50) } \\
\text { fractions } 22-42(147 \mathrm{ml})\end{array}$ & 3.6 & $20 \cdot 0$ & $5 \cdot 7$ & $65 \cdot 8$ & $7 \cdot 5$ \\
\hline $\begin{array}{l}\text { Bio Gel P-200 fractions } \\
33-41(22.5 \mathrm{ml})\end{array}$ & $1 \cdot 0$ & 17.0 & 17.0 & $55 \cdot 7$ & $22 \cdot 8$ \\
\hline $\begin{array}{l}\text { Bio Gel P-60 fractions } \\
18-25(9 \mathrm{ml})\end{array}$ & $0 \cdot 3$ & $15 \cdot 0$ & $50 \cdot 0$ & $44 \cdot 1$ & 67.24 \\
\hline
\end{tabular}

optima of the enzymes : 3.5 for the low molecular weight enzyme and $5 \cdot 0$ for the higher molecular weight enzyme.

There are reports of the production of more than one endoxylanase by micro-organisms; these enzymes are very similar low molecular weight proteins sometimes separable only by isoelectric focusing (Comtat, 1983). In contrast, our results demonstrate the production of two endoxylanases, with widely different molecular weights but similar physicochemical properties, by $T$. clypeatus under different nutritional conditions.

The authors are grateful to Professor B. K. Bachhawat, director of the Institute, for his kind interest and valuable suggestions during the progress of the work.

\section{REFERENCES}

Cisar, J., Kabat, E. A., Dorner, M. M. \& Liao, J. (1975). Binding properties of immunoglobulin combining sites specific for terminal or nonterminal antigen determinants in dextran. Journal of Experimental Medicine 142, 435-458.

COMTAT, J. (1983). Isolation, properties and postulated role of some xylanases from the basidiomycete Sporotrichum dimorphosporium. Carbohydrate Research 118, 215-223.

DAvis, B. J. (1964). Disk electrophoresis. II. Method and application to human serum proteins. Annals of the New York Academy of Sciences 121, 404-427. 
DEKKER, R. F. H. \& RICHARDS, G. N. (1976). Hemicellulases: their occurrence, purification, properties and mode of action. Advances in Carbohydrate Chemistry and Biochemistry 22, 227-252.

Ghosh, A. K. \& Sengupta, S. (1978). Studies on biochemistry of higher fungi. II. Submerged growth of a few mushrooms in synthetic media. Journal of Food Science and Technology 15, 237-242.

Ghosh, A. K., Banerjee, P. C. \& Sengupta, S. (1980). Purification and properties of xylan hydrolase from mushroom Termitomyces clypeatus. Biochimica et biophysica acta 612, 143-152.

LAEMMLI, U. K. (1970). Cleavage of structural proteins during the assembly of the head of bacteriophage $T_{4}$. Nature, London 227, 680-685.

NELSON, N. (1944). A photometric adaption of the Somogyi method for the determination of glucose. Journal of Biological Chemistry 153, 375-380.

Rufo, G. A., JR, Singh, J. P., BABCOCK, D. F. \& LARDY, H. A. (1982). Purification and characterization of a calcium transport inhibitor protein from bovine seminal plasma. Journal of Biological Chemistry 257, 4627-4632.

SOMOGYI, M. (1952). Notes on sugar determination. Journal of Biological Chemistry 195, 19-23. 